\begin{tabular}{|c|l|}
\hline Title & An electrophoretic analysis of superoxide dismutase in Campy lobacter spp. \\
\hline Author(s) & KIKUCHI, Hiroko E.; SUZUKI, Takeshi \\
\hline Citation & Journal of General Microbiology, 130, 2791-2796 \\
\hline Issue Date & 1984 \\
\hline Doc URL & http://hdl.handle.net/2115/29927 \\
\hline Rights & @1984 Society for General Microbiology \\
\hline Type & article \\
\hline File Information & JGM130.pdf \\
\hline
\end{tabular}

Instructions for use 


\title{
An Electrophoretic Analysis of Superoxide Dismutase in Campylobacter spp.
}

\author{
By HIROKO E. KIKUCHI* AND TAKESHI SUZUKI \\ Department of Oral Microbiology, School of Dentistry, Hokkaido University, Sapporo 060, Japan
}

(Received 22 May 1984; revised 29 June 1984)

Superoxide dismutase (SOD, superoxide: superoxide reductase, EC 1.15.1.1) activity was studied in 23 strains of Campylobacter spp. using disc polyacrylamide gel electrophoresis. Different enzyme patterns were observed with extracts of different species of Campylobacter; three migration bands were found in all strains of $C$. sputorum subsp. sputorum and C. sputorum subsp. bubulus (relative mobilities, $\mathrm{Rm}, 0.57,0.76$ and 0.85 ), and $C$. fetus subsp. fetus ( $\mathrm{Rm} 0.60,0.72$ and 0.81 ), while four migration bands ( $\mathrm{Rm} 0.52,0.57,0.73$ and 0.82 ) were found in $C$. fetus subsp. venerealis. One band ( $\mathrm{Rm} 0.73$ ) was found in $C$. coli $\mathrm{CIP} 7080$ and two bands $(\mathrm{Rm} 0.59,0.73)$ in C. jejuni CIP 702. Superoxide dismutase activities were very high in the Campylobacter strains, especially in $C$. fetus subsp. fetus [specific activity $7 \cdot 8-55.7 \mathrm{U}$ (mg protein $)^{-1}$ ] compared with those in Escherichia coli $\left(1.5 \mathrm{U} \mathrm{mg}^{-1}\right)$, Propionibacterium acnes $\left(1.6 \mathrm{U} \mathrm{mg}^{-1}\right)$ and Veillonella alcalescens $\left(0 \cdot 2 \mathrm{U} \mathrm{mg}^{-1}\right)$.

\section{INTRODUCTION}

Campylobacter jejuni is the causative agent of a bacterial diarrhoea in man (Newell, 1982; Skirrow, 1977; Smibert, 1978). Campylobacter fetus causes sterility and abortion in cattle (Smith, 1978). Campylobacter coli has been isolated from pig intestines and is reported to increase in number when the pig suffers from dysentery (Doyle, 1944). Catalase-negative non-pathogenic Campylobacter spp. found in normal reproductive organs of cattle, the human oral cavity and porcine intestinal mucosa were named C. sputorum subsp. sputorum, C. sputorum subsp. bubulus (Loesche et al., 1965) and C. sputorum subsp. mucosalis (Lawson et al., 1975), respectively, following the classification scheme of Véron \& Chatelain (1973).

Campylobacter spp. have also been found associated with purulent pyorrhoea (Dwyer \& Socransky, 1968; Slots et al., 1978). Other Campylobacter spp. found in dental pockets of humans with periodontitis have been identified as $C$. concisus although Tanner \& Badger (1981) reported that these species were serologically distinct from other Campylobacter species including C. sputorum and $C$. fetus and that some strains showed cross activities with antiserum obtained from Wolinella recta. Further taxonomic and biochemical studies are required on these oral Campylobacter spp.

Several reports have shown the optimal growth atmosphere for Campylobacter spp. to be $5 \%$ (v/v) oxygen (Kiggens \& Plastridge, 1956; Ware et al., 1977), 6\% (Reich et al., 1956) or 2.5\% (Fletcher \& Plastridge, 1964), suggesting that they may have a special superoxide dismutase (SOD). We have observed the growth of Campylobacter spp. in GAM semi-solid medium, a medium for the growth of anaerobic bacteria. Isolates grew $2.5 \mathrm{~mm}$ below the surface of this medium; different species and subspecies of Campylobacter grew at different rates at the same depth.

Hoffman et al. $(1979 a, b)$ reported that two strains of $C$. jejuni and one strain of $C$. fetus subsp. fetus showed different SOD activity staining patterns on disc polyacrylamide gel electrophoretograms. It was suggested that a particular isoenzyme of SOD might be related to the aero-

Abbreviations: NBT, nitroblue tetrazolium; Rm, relative mobility; SOD, superoxide dismutase. 
Table 1. Strains of Campylobacter and other bacteria used

Received as

\begin{tabular}{|c|c|c|c|}
\hline Name & Strain & Source* & Habitat \\
\hline C. sputorum subsp. sputorum & $\begin{array}{l}\text { C } 1 \\
\text { C } 2 \\
\text { C } 3 \\
\text { C } 4 \\
\text { C } 5 \\
\text { C } 6 \\
\text { C } 8 \\
\text { C } 9 \\
\text { C } 14 \\
\text { C } 15\end{array}$ & $\left.\begin{array}{l}\text { NIAH } \\
\text { NIAH } \\
\text { NIAH } \\
\text { NIAH } \\
\text { NIAH } \\
\text { NIAH } \\
\text { NIAH } \\
\text { NIAH } \\
\text { NIAH } \\
\text { NIAH }\end{array}\right\}$ & Bull foreskin cavity wash \\
\hline C. sputorum subsp. bubulus & CIP 53103† & CIP & Bull sperm \\
\hline C. coli & CIP $7080 \dagger$ & CIP & Faeces of pig \\
\hline C. jejuni & CIP $702 \dagger$ & CIP & Faeces of cow \\
\hline C. fetus subsp. fetus & $\begin{array}{l}\text { CIP } 5396 \dagger \\
\text { C } 16 \\
\text { C } 17 \\
\text { C } 18 \\
\text { C } 20\end{array}$ & $\left.\begin{array}{l}\text { CIP } \\
\text { NIAH } \\
\text { NIAH } \\
\text { NIAH } \\
\text { NIAH }\end{array}\right\}$ & $\begin{array}{l}\text { Brain of sheep foetus } \\
\text { Bull foreskin cavity wash }\end{array}$ \\
\hline C. fetus subsp. venerealis & $\begin{array}{l}\text { CIP } 6829 \dagger \\
\text { C } 21 \\
\text { C } 22 \\
\text { C } 23 \\
\text { C } 24\end{array}$ & $\begin{array}{l}\text { CIP } \\
\text { NIAH } \\
\text { NIAH } \\
\text { NIAH } \\
\text { NIAH }\end{array}$ & $\begin{array}{l}\text { Cow } \\
\text { Bone of abortive cow embryo } \\
\text { Liver of abortive cow embryo } \\
\text { Caecum of abortive cow embryo }\end{array}$ \\
\hline $\begin{array}{l}\text { Escherichia coli } \\
\text { Propionibacterium acnes } \\
\text { Veillonella alcalescens subsp. dispar }\end{array}$ & $\begin{array}{l}\text { IID } 861 \dagger \\
\text { ATCC } 11827 \dagger \\
\text { ATCC } 17748 \dagger\end{array}$ & $\begin{array}{l}\text { IID } \\
\text { ATCC } \\
\text { ATCC }\end{array}$ & Human mouth \\
\hline
\end{tabular}

* CIP, Collection of the Institute Pasteur, Paris, France; IID, Institute of Medical Science, University of Tokyo, Tokyo, Japan; ATCC, American Type Culture Collection, Rockville, Md., USA; NIAH, National Institute of Animal Health (Hokkaido Branch Laboratory), Sapporo, Japan.

$\uparrow$ Type strain.

tolerance of $C$. fetus (Hoffman et al., 1979a). In order to extend our knowledge of SOD of Campylobacter spp. in relation to their microaerophilic characteristics and species differences, we have studied SOD of $C$. sputorum subsp. sputorum, C. fetus subsp. fetus, C. fetus subsp. venerealis and other campylobacters by disc polyacrylamide gel electrophoresis.

\section{METHODS}

Organisms. The strains used are listed in Table 1, with their sources and habitats.

Media and cultivation. Campylobacter strains were grown in GAM broth (Nissui Co., Tokyo, Japan) placed in Petri dishes to give a large surface area. The composition of GAM broth, which is a medium for the growth of anaerobic bacteria, is as follows $\left(\left(^{-1}\right)\right.$ : peptone $10.0 \mathrm{~g}$; soybean peptone $3.0 \mathrm{~g}$; proteose peptone $\mathrm{W} 10.0 \mathrm{~g}$; digested serum $13.5 \mathrm{~g}$; yeast extract $5.0 \mathrm{~g}$; beef extract $2.2 \mathrm{~g}$; liver extract $1.2 \mathrm{~g}$; glucose $3.0 \mathrm{~g} ; \mathrm{KH}_{2} \mathrm{PO}_{4} 2.5 \mathrm{~g} ; \mathrm{NaCl} 3.0 \mathrm{~g}$; soluble starch $0.3 \mathrm{~g} ; \mathrm{L}$-cystine. $\mathrm{HCl} 0.3 \mathrm{~g}$; sodium thioglycollate $0.3 \mathrm{~g}$. The $\mathrm{pH}$ was adjusted to $7 \cdot 3 \pm 0 \cdot 1$. The inoculum was grown in GAM semi-solid medium (GAM broth containing $1.5 \mathrm{~g}$ agar $1^{-1}$ ) in Erlenmeyer flasks.

Propionibacterium acnes and Veillonella alcalescens were grown in Erlenmeyer flasks filled to the top with GAM broth. Escherichia coli was grown in nutrient broth containing $\left(1^{-1}\right)$ : meat extract $5 \mathrm{~g}$; peptone $10 \mathrm{~g} ; \mathrm{NaCl} 5 \mathrm{~g}$ (Eiken Co., Tokyo, Japan).

All bacteria were cultured at $37^{\circ} \mathrm{C}$. Escherichia coli was harvested by centrifugation after $18 \mathrm{~h}$ growth and other bacteria after $48 \mathrm{~h}$.

Preparation. Harvested cells were sedimented $(7500 \mathrm{~g}$ for $10 \mathrm{~min})$, washed three times with physiological saline $\left(0.15 \mathrm{M}-\mathrm{NaCl}\right.$ ), and suspended in saline at $0.5 \mathrm{~g}$ wet $\mathrm{wt} \mathrm{m}^{-1}$. After sonication at $20 \mathrm{kHz}$ at $80 \mathrm{~W}$ for $3 \mathrm{~min}$ (Tomy, Ultrasonic UR 200, Japan), the homogenate was centrifuged at $12000 \mathrm{~g}$ for $60 \mathrm{~min}$ (Sorvall, RC-5). The supernatant was dialysed for $36 \mathrm{~h}$ in $0.02 \mathrm{M}$-phosphate buffer $(\mathrm{pH} 7.8)$ to remove $\mathrm{Cu}^{2+}, \mathrm{Mn}^{2+}, \mathrm{Fe}^{2+}$ and $\mathrm{Fe}^{3+}$ ions that may affect SOD activity and salts that may affect electrophoresis.

Determination of protein content and enzyme activities. Protein content was determined by the Lowry method. 
SOD activity of the dialysed solutions was measured by the xanthine/xanthine oxidase/nitroblue tetrazolium (NBT) system (McCord \& Fridovich, 1969). Xanthine oxidase was added to $3 \mathrm{ml}$ reaction mixture solution containing $1 \times 10^{-4} \mathrm{M}$-xanthine, $2.5 \times 10^{-5} \mathrm{M}$-NBT, $1 \times 10^{-4} \mathrm{M}$-EDTA and $0.05 \mathrm{M}$-sodium carbonate $(\mathrm{pH} 10 \cdot 2)$ in an amount sufficient to reduce NBT to diformazan at a rate such that the $A_{560}$ increased at 0.01 unit $\min ^{-1}$ at $25^{\circ} \mathrm{C}$ (Hitachi spectrophotometer 200-20). The amount of SOD required to inhibit the rate of reduction of NBT by $50 \%$ under these defined conditions is defined as 1 unit of activity.

Catalase activity was detected by effervescence in $3 \%(\mathrm{v} / \mathrm{v})$ hydrogen peroxide. Oxidase activity was detected using the dimethyl-p-phenylenediamine dihydrochloride reagent of Kovacs (1956).

Electrophoresis and staining. A dialysed solution of protein $(0.1-0.3 \mathrm{mg})$ was electrophoresed on $7 \%(\mathrm{w} / \mathrm{v})$ polyacrylamide disc gels using the method of Davis \& Ornstein (1964). Running gels (pH 8.9) $6 \mathrm{~cm}$ long with $1 \mathrm{~cm}$ thick spacer gels were prepared in glass gel tubes of inner diameter $5 \mathrm{~mm}$, and set in a cooling device. After stacking $50 \mu \mathrm{l} 40 \%(\mathrm{w} / \mathrm{v})$ sucrose solution containing protein and bromophenol blue, the gels were run at $5 \mathrm{~mA}$ per tube for $40 \mathrm{~min}$ at $12^{\circ} \mathrm{C}$ in a buffer solution containing $0.6 \mathrm{~g}$ Tris and $2.88 \mathrm{~g}$ glycine $1^{-1}$ (pH 8.3).

SOD was detected by soaking the gels in $2.45 \mathrm{mM}$-NBT for $20 \mathrm{~min}$ followed by immersion for $15 \mathrm{~min}$ in a solution containing $28 \mathrm{~mm}$-tetramethylenediamine, $28 \mu \mathrm{M}$-riboflavin and $36 \mathrm{~mm}$-potassium phosphate ( $\mathrm{pH} 7.8$ ). The gels were then placed in small dry test tubes and illuminated for 5 to $15 \mathrm{~min}$ with a commercial $20 \mathrm{~W}$ fluorescent lamp (360-740 $\mathrm{nm}$ including line spectra at 400 and $435 \mathrm{~nm}$ ) at a distance of $10 \mathrm{~cm}$. During illumination, the gels turned blue except for the bands containing SOD. Illumination was stopped when maximum contrast was achieved between the unstained and blue zones (Beauchamp \& Fridovich, 1971). Migration distances of negativestained bands were converted to relative mobilities $(\mathrm{Rm})$ by dividing each migration distance by that of the front marker (bromophenol blue).

Each sample was electrophoresed on two gels; one gel was stained without $\mathrm{KCN}$ and the other was stained in the presence of $2 \mathrm{~mm}-\mathrm{KCN}$ (De Rosa et al., 1979) in order to detect the presence of $\mathrm{Zn}, \mathrm{Cu}-\mathrm{SOD}$ (Weisiger \& Fridovich, 1973). Dismutation of $\mathrm{O}_{2}^{-}$by $\mathrm{Zn}, \mathrm{Cu}-\mathrm{SOD}$ is inhibited by $\mathrm{CN}^{-}$, while Fe-SOD and Mn-SOD activities are unaffected by $\mathrm{CN}^{-}$(Fridovich, 1974).

Three to nine cultures of each strain were analysed for all enzyme activities. Bovine blood SOD (Sigma) was used as a control.

\section{RESULTS}

The specific activities of SOD obtained for homogenates of each strain are given in Table 2. Extracts of $E$. coli and $P$. acnes had SOD specific activities of around $1.5 \mathrm{U}$ (mg protein $)^{-1}$. Extracts of $V$. alcalescens showed negligible activity. Extracts of Campylobacter spp. had SOD specific activities that ranged from about $1 \mathrm{U}$ (mg protein $)^{-1}$ in C. sputorum subsp. sputorum to above $50 \mathrm{U}$ (mg protein) $)^{-1}$ in $C$. fetus subsp. fetus. The SOD specific activities of $C$. sputorum subsp. sputorum and $C$. fetus subsp. venerealis were similar [means \pm SD $3.4 \pm 1.8$ and $4.7 \pm$ $1.3 \mathrm{U}$ (mg protein $)^{-1}$, respectively]. While C. fetus subsp. fetus had much higher activities and also showed large activity variations between different strains [mean \pm SD $30.5 \pm 17.5 \mathrm{U}$ (mg protein $)^{-1}$ for the five strains studied], variations within strains were not large in comparison with those found in $C$. fetus subsp. venerealis. The SOD specific activities of $C$. coli, $C$. jejuni and C. sputorum subsp. bubulus were between those of $C$. sputorum subsp. sputorum and $C$. fetus subsp. fetus. The mean SOD specific activity determined for the Campylobacter strains other than $C$. fetus subsp. fetus was $5 \cdot 4 \pm 2 \cdot 2 \mathrm{U}$ (mg protein $)^{-1}$.

All the Campylobacter strains had oxidase activity, and all except $C$. sputorum subsp. sputorum and $C$. sputorum subsp. bubulus had catalase activity. Escherichia coli, $P$. acnes and V.alcalescens did not have oxidase activity and $P$. acnes did not have catalase.

Fig. 1 shows the positions of bands stained for SOD activity after polyacrylamide disc electrophoresis of extracts of Campylobacter spp. together with those obtained for bovine blood SOD and extracts of E. coli, $V$. alcalescens and P. acnes. Different SOD profiles were obtained with extracts of different campylobacters. Campylobacter sputorum subsp. sputorum had one clear band of $\mathrm{Rm} 0.57$ and two minor bands of $\mathrm{Rm} 0.76$ and 0.85 . Campylobacter sputorum subsp. bubulus had a very similar profile consisting of three bands of $\mathrm{Rm} 0.56,0.76$ and $0.85 ;$ C. coli had only one clear band of $\mathrm{Rm} 0.73$; C. jejuni had two bands of $\mathrm{Rm} 0.59$ and 0.73 ; C. fetus subsp. fetus had a minor band of $\operatorname{Rm} 0.60$, a major band of $\operatorname{Rm} 0.72$ and an intermediate band of $\operatorname{Rm} 0.81 ; C$. fetus subsp. venerealis had two clear bands of $\operatorname{Rm} 0.73$ and 0.82 and two trace bands of $\operatorname{Rm} 0.52$ and 0.57 . The SOD profiles of the different isolates were identical for a given species or subspecies. 
Table 2. Activities of SOD and other enzymes in Campylobacter, E. coli, P. acnes and $V$. alcalescens

\begin{tabular}{|c|c|c|c|c|}
\hline Organism & & $\begin{array}{l}\text { Sp. act. of SOD } \\
{\left[\mathrm{U}(\mathrm{mg} \text { protein) })^{-1}\right]}\end{array}$ & $\begin{array}{l}\text { Catalase } \\
\text { activity }\end{array}$ & $\begin{array}{l}\text { Oxidase } \\
\text { activity }\end{array}$ \\
\hline C. sputorum subsp. sputorum & $\begin{array}{ll}\text { C } & 1 \\
\text { C } & 2 \\
\text { C } & 3 \\
\text { C } & 4 \\
\text { C } & 5 \\
\text { C } & 6 \\
\text { C } & 8 \\
\text { C } & 9 \\
\text { C } & 14 \\
\text { C } & 15\end{array}$ & $\begin{array}{l}4.8 \pm 0.4 \\
4.8 \pm 0.4 \\
3.2 \pm 0.2 \\
4.5 \pm 0.3 \\
3.8 \pm 0.3 \\
1.8 \pm 0.1 \\
0.9 \pm 0.1 \\
6.5 \pm 0.5 \\
1.7 \pm 0.0 \\
1.9 \pm 0.8\end{array}$ & $\begin{array}{l}- \\
- \\
- \\
- \\
- \\
- \\
- \\
- \\
- \\
-\end{array}$ & $\begin{array}{l}+ \\
+ \\
+ \\
+ \\
+ \\
+ \\
+ \\
+ \\
+ \\
+\end{array}$ \\
\hline C. sputorum subsp. bubulus & CIP 53103 & $5.8 \pm 1.0$ & - & + \\
\hline C. coli & CIP 7080 & $3.9 \pm 0.5$ & + & + \\
\hline C. jejuni & CIP 702 & $9 \cdot 0 \pm 1.8$ & + & + \\
\hline C. fetus subsp. fetus & $\begin{array}{l}\text { CIP } 5396 \\
\text { C } 16 \\
\text { C } 17 \\
\text { C } 18 \\
\text { C } 20\end{array}$ & $\begin{array}{r}14.0 \pm 2.7 \\
7.8 \pm 3.8 \\
40.0 \pm 2.4 \\
35.2 \pm 3.0 \\
55.7 \pm 2.8\end{array}$ & $\begin{array}{l}+ \\
+ \\
+ \\
+ \\
+\end{array}$ & $\begin{array}{l}+ \\
+ \\
+ \\
+ \\
+\end{array}$ \\
\hline C. fetus subsp. venerealis & $\begin{array}{l}\text { CIP } 6829 \\
\text { C } 21 \\
\text { C } 22 \\
\text { C } 23 \\
\text { C } 24\end{array}$ & $\begin{array}{l}5.3 \pm 1.6 \\
6.8 \pm 0.1 \\
3.9 \pm 0.2 \\
2.9 \pm 0.3 \\
4.4 \pm 0.1\end{array}$ & $\begin{array}{l}+ \\
+ \\
+ \\
+ \\
+\end{array}$ & $\begin{array}{l}+ \\
+ \\
+ \\
+ \\
+\end{array}$ \\
\hline E. coli & IID 861 & $1.5 \pm 0.1$ & + & - \\
\hline P. acnes & ATCC 11827 & $1.6 \pm 0.0$ & - & - \\
\hline V. alcalescens subsp. dispar & ATCC 17748 & $0.2 \pm 0.0$ & + & - \\
\hline
\end{tabular}

* Mean of three to nine determinations, $\pm \mathrm{SD}$.

No inhibition of SOD activity by $2 \mathrm{mM}-\mathrm{KCN}$ was observed, indicating that the enzymes in Campylobacter spp. are of the Fe-SOD and/or Mn-SOD types.

\section{DISCUSSION}

The species and subspecies of Campylobacter we studied had SOD activities higher than those of $E$. coli and $P$. acnes. Most of the campylobacters showed specific activities of around $5 \mathrm{U}(\mathrm{mg}$ protein $)^{-1}$. Campylobacter fetus subsp. fetus showed much higher specific activities.

It is possible to relate to some extent the SOD activity in the Campylobacter spp. to their aerotolerance. The oxygen partial pressure at which the growth of a particular isolate is inhibited was reported as follows: $C$. sputorum $5 \cdot 3-10 \cdot 7 \mathrm{kPa}\left(5 \cdot 2-10.6 \% \mathrm{O}_{2}\right)$ (Loesch et al., 1965), $C$. jejuni $6.1 \mathrm{kPa}\left(6 \% \mathrm{O}_{2}\right)$ (Hoffman et al., 1979a), C. fetus subsp. venerealis $8.6 \mathrm{kPa}\left(8.5 \% \mathrm{O}_{2}\right)$, C. coli $12.7 \mathrm{kPa}\left(12.5 \% \mathrm{O}_{2}\right)$, and $C$. fetus subsp. fetus $18.1 \mathrm{kPa}\left(17.9 \% \mathrm{O}_{2}\right)$ (Ware et al., 1977). Thus aerotolerance increases with increase in the SOD activity.

Catalase is another important factor in the aerotolerance of a bacterium. Since our $C$. sputorum strains had no significant catalase activity, SOD may be dominant in preventing oxygen damage in these organisms. Oxygen utilization is indicated in all the Campylobacter strains studied, by the presence of a positive oxidase reaction.

The migration patterns shown in Fig. 1 suggest that Campylobacter spp. have several electrophoretically distinct variants of SOD. An isoenzyme of Rm 0.57 was the main component in $C$. sputorum, while an isoenzyme of $\mathrm{Rm} 0.73$ is the characteristic main component of both C. fetus subspp. and of $C$. jejuni. However, $C$. jejuni is distinguishable from $C$. fetus by the absence of a second major isoenzyme of $\mathrm{Rm} 0.82$. Campylobacter fetus subsp. fetus and $C$. fetus subsp. vener- 


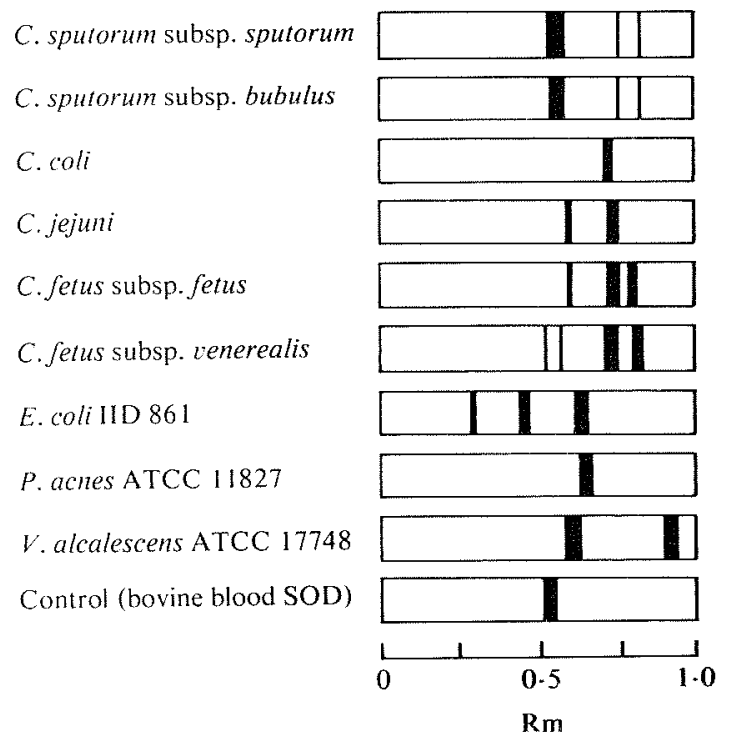

Fig. 1. Drawings of electrophoretic migration patterns of SOD of six species/subspecies of Campylobacter, and of E. coli, P. acnes and V. alcalescens (control: bovine blood SOD). Crude cell-free extracts were subjected to electrophoresis, using 0.1 to $0.3 \mathrm{mg}$ protein per gel. The gels $(7 \%$ acrylamide) were stained for superoxide dismutase. Migration distances of negative-stained bands were converted to relative mobilities $(\mathrm{Rm})$ by dividing each migration distance by that of the front marker (bromophenol blue).

ealis have similar main bands ( $\operatorname{Rm} 0.72,0.81$ and $\mathrm{Rm} 0.73,0.82)$ but they can be distinguished from each other since the latter has two trace bands $(\operatorname{Rm} 0.52,0.57)$, and the former only one ( $\mathrm{Rm} 0 \cdot 60)$.

Contrary to the results of Ware et al. (1977), inhibition of SOD activity by $\mathrm{CN}^{-}$was not observed. Our results are thus in line with evidence that bacteria do not have $\mathrm{Zn}, \mathrm{Cu}-\mathrm{SOD}$ (Fridovich, 1974). Hoffman et al. (1979b) reported that the SOD of C. jejuni was an Fe-type enzyme. In view of the various enzyme activities and different electrophoretic profiles of SOD in Campylobacter spp., it seems probable that some species or subspecies of Campylobacter may also have Mn-SOD. The higher SOD activities and large activity variations in $C$. fetus subsp. fetus might be due to an active synthesis of Fe-SOD and/or Mn-SOD.

In conclusion, the present results indicate that the electrophoretic analysis of SOD may be useful in distinguishing C. sputorum, C. coli, C. jejuni, C. fetus subsp. fetus and C. fetus subsp. venerealis.

The authors thank Dr Hashimoto, The Hokkaido Branch Laboratory, National Institute of Animal Health, for kindly giving the strains of Campylobacter.

\section{REFERENCES}

Beauchamp, C. \& Fridovich, I. (1971). Superoxide dismutase: improved assays and an assay applicable to acrylamide gels. Analytical Biochemistry 44, 276287.

Davis, B. J. \& ORNSTEIN, L. (1964). Disc electrophoresis I. Background and theory. Annals of the New York Academy of Sciences 121, 321-404.

De Rosa, G., Duncan, D. S., Keen, C. L. \& Hurley, L. S. (1979). Evaluation of negative staining technique for determination of $\mathrm{CN}$-insensitive superoxide dismutase activity. Biochimica et biophysica acta 566, 32-39.

DOYLE, L. P. (1944). A Vibrio associated with swine dysentery. American Journal of Veterinary Research $\mathbf{5}$, 3-5.

Dwyer, D. M. \& Socransky, S. S. (1968). Predominant cultivable micro-organisms inhabiting periodontal pockets. British Dental Journal 124, 560564.

Fletcher, R. D. \& Plastridge, W. N. (1964). Gaseous environment and growth of microaerophilic vibrios. Journal of Bacteriology 87, 352355.

Fridovich, I. (1974). Superoxide dismutase (review). Advances in Enzymology 14, 35-97.

Hoffman, P. S., Krieg, N. R. \& Smibert, R. M. 
$(1979 a)$. Studies of the microaerophilic nature of Campylobacter fetus subsp. jejuni. I. Physiological aspects of enhanced aerotolerance. Canadian Journal of Microbiology 25, 1-7.

HoffMAN, P. S., GEORGE, H. A., KRIEG, N. R. \& SMIBERT, R. M. (1979b). Studies of the microaerophilic nature of Campylobacter fetus subsp. jejuni. II. Role of exogenous superoxide anions and hydrogen peroxide. Canadian Journal of Microbiology 25, 8-16.

Kiggens, E. M. \& Plastridge, W. N. (1956). Effect of gaseous environment on growth and catalase content of Vibrio fetus cultures of bovine origin. Journal of Bacteriology 72, 397-400.

Kovacs, N. (1956). Identification of Pseudomonas pyocyanea by the oxidase reaction. Nature, London 178, 703-704.

Lawson, G. H. K., Rowland, A. C. \& Wooding, P. (1975). The characterisation of Campylobacter sputorum subspecies mucosalis isolated from pigs. Research in Veterinary Science 18, 121-126.

Loesche, W. J., Gibbons, R. J. \& Socransky, S. S. (1965). Biological characteristics of Vibrio sputorum and relationship to Vibrio bubulus and Vibrio fetus. Journal of Bacteriology 89, 1109-1116.

MCCord, J. M. \& Fridovich, I. (1969). Superoxide dismutase. Journal of Biological Chemistry 244, 60496055 .

Newell, D. G. (1982). Campylobacter. Lancaster: MTP Press.

Reich, C. V., Morse, E. V. \& Wilson, J. B. (1956).
Gaseous requirements for growth of Vibrio fetus. American Journal of Veterinary Research 17, 140-143.

SkIRrow, M. B. (1977). Campylobacter enteritis: a 'new' disease. British Medical Journal 2, 9-11.

Slots, J., Moenbo, D., Langebaek, J. \& Frandsen, A. (1978). Microbiota of gingivitis in man. Scandinavian Journal of Dental Research 86, 174-181.

SmiberT, R. M. (1978). The genus Campylobacter. Annual Review of Microbiology 32, 673-709.

SMITH, T. (1978). Spirilla associated with disease of fetal membrane in cattle (infectious abortion). Journal of Experimental Medicine 28, 701-704.

TANNER, A. C. R. \& BADGER, S. J. (1981). Serological studies of Bacteroides gracilis, Campylobacter concisus, Wolinella recta, and Eikenella corrodens, all from humans with periodontal disease. International Journal of Systematic Bacteriology 31, 446-451.

Véron, M. \& Chatelain R. (1973). Taxonomic study of genus Campylobacter Sebald and Véron and designation of the neotype strain for the type species, Campylobacter fetus (Smith and Taylor) Sebald and Véron. International Journal of Systematic Bacteriology 31, 446-451.

Ware, D. A., Colley, P. J. \& Park, R. W. A. (1977). Oxygen requirement and sensitivity of Campylobacter spp. Proceedings of the Society for General Microbiology 5, 19 (abstract).

WeIsiger, R. A. \& Fridovich, I. (1973). Superoxide dismutase. Organelle specificity. Journal of Biological Chemistry 248, 3582-3592. 